\title{
Analisis Akad Mudharabah di Perbankan Syariah
}

\author{
Hidayati Nasrah \\ Fakultas Ekonomi dan Ilmu Sosial UIN Sultan Syarif Kasim Riau \\ E-mail : hidayatinasrah@gmail.com
}

\begin{abstract}
This study tried to see mudharabah practices by Islamic banks, whether the implementation and practice mudharabah is in accordance with Islamic Shari'a. In this study also described the practice of gift-giving in early when customers deposit funds in Islamic banks. Practices carried out by the Islamic Bank raises a lot of criticism from people who think that Islamic banks are not different from conventional banks, only the title that sharia. The study was conducted with descriptive methods, compare theory derived from the study of literature with the practice in the field. The study found there are many Islamic banking practices in the implementation of mudharabah, particularly in terms of capital ownership status and responsibility to bear the risk violate what is outlined in the Shariah. In terms of gift-giving at the beginning, it was found that the gift made Islamic banks with a specific purpose, grant can not be justified in Shari'a.
\end{abstract}

Key words: Islamic Banking, mudaraba contract, grant

\section{PENDAHULUAN}

Islam sebagai agama yang rahmatan lil alamin merupakan agama yang menekankan pentingnya sistem keadilan di masyarakat. AlQur'an sebagai kitab suci umat Islam menekankan keadilan. Keadilan menekankan persamaan untuk semua pihak, dan system keadilan ini seratus persen berseberangan dengan penumpukan dan penimbunan harta kekayaan, sehingga al-Qur'an tidak menginginkan harta kekayaan itu hanya berputar diantara orang-orang kaya saja (Al Quran surat Al Hasyr $59: 7)$.

Untuk memperoleh harta, manusia dengan nafsunya melakukan apa saja demi mencapai apa yang diinginkannya. Kadangkala hak-hak orang lain menjadi terabaikan, dan sesuatu yang diperoleh seringkali berasal dari mengeksploitasi orang lain. Tujuan nyata dari masyarakat Islam adalah membebaskan manusia dan ini hanya bisa di lakukan di dalam suatu masyarakat dimana kekayaan bukan diperoleh dengan "kekuatan" namun dengan "hasil kerja" (Ashgar, 2006 : 158).

Praktik ekonomi yang ada dalam sistem kapitalistik hanya akan menambah penderitaan dan eksploitasi terhadap masyarakat kalangan bawah. Masyarakat kalangan bawah ini tidak berdaya melawan kekuatan modal, karena dirinya tidak mempunyai kekuatan untuk menentukan kebijakankebijakan untuk mendapatkan hakhak-nya sebagai manusia.

Praktik-Praktik kapitalistik pada hakikatnya telah ada semenjak zaman pra Islam sekalipun. 
Penduduk Mekah sebelum datangnya Islam diliputi kesengsaraan khususnya pada golongan masyarakat lemah. Struktur ekonomi kesukuan mengalami keruntuhan, kemudian datanglah oligarki perdagangan. Oligarki tumbuh karena keserakahan terhadap materi dan bahkan kemudian secara terangterangan aturan-aturan kesukuan tidak lagi dihiraukan. Akibatnya anak-anak yatim, janda-janda dan orang-orang miskin mengalami penderitaan yang luar biasa ((Ashgar, $2006: 3$ ).

Kedatangan Islam melalui perjuangan Nabi Muhamad SAW. Telah banyak merekayasa situasi sosial dan ekonomi pada waktu itu, sehingga konsep Islam khususnya dalam perekonomian membawa kesadaran bagi kaum muslimin untuk menerapkan konsep ekonomi yang sesuai dengan tuntunan Al-qur'an dan Sunah.

Salah satu konsep muamalah yang terdapat dalam sistem ekonomi Islam adalah mudharabah. Sistem ini sedikit banyaknya telah diterapkan dalam kehidupan masyarakat muslim. Para ulama klasik telah banyak mengupas mengenai sistem mudharabah ini. Namun, di zaman moderen sekarang ini konsep mudharabah lebih di kontekstualkan lagi terlebih setelah adanya lembaga keuangan semisal Bank.

Mudharabah adalah akad yang telah dikenal oleh umat muslim sejak zaman Nabi, bahkan telah dipraktikkan oleh bangsa Arab sebelum turunnya Islam. Ketika Nabi Muhammad Saw berprofesi sebagai pedagang ia telah melakukan akad mudharabah dengan Khadijah (Karim, 2006 : 204)
Pada saat itu Khadijah mempercayakan barang dagangannya untuk dijual oleh Nabi Muhammad ke luar negeri. Dalam kasus ini Khadijah berperan sebagai pemilik modal (shahib al maal) sedangkan Nabi Muhammmad berperan sebagai pelaksana usaha (mudharib).

Akad Mudharabah adalah akad yang oleh para ulama telah disepakati akan kehalalannya. Karena itu, akad ini dianggap sebagai tulang punggung praktek perbankan syariah. Dewan Syariah NasionalMajelis Ulama Indonesia (DSNMUI) telah menerbitkan fatwa no: 07/DSN-MUI/IV/2000, yang kemudian menjadi pedoman bagi praktek perbankan syariah, akan tetapi praktek bank syariah yang dilakukan saat ini perlu ditinjau ulang.

Pada fatwa tersebut, DSN menyatakan: "Lembaga Keuangan Syariah (LKS) sebagai penyedia dana, menanggung semua kerugian akibat dari mudharabah kecuali jika mudharib (nasabah) melakukan kesalahan yang disengaja, lalai, atau menyalahi perjanjian."(DSN-MUI, 2000). Pada ketentuan lainnya, DSN kembali menekankan akan hal ini dengan pernyataan: "Penyedia dana menanggung semua kerugian akibat dari mudharabah, dan pengelola tidak boleh menanggung kerugian apapun, kecuali diakibatkan dari kesalahan disengaja, kelalaian, atau pelanggaran kesepakatan."(DSNMUI, 2000)

Praktek perbankan syariah di lapangan masih jauh dari apa yang di fatwakan oleh DSN. Andai perbankan syariah benar-benar menerapkan ketentuan ini, niscaya masyarakat berbondong-bondong 
mengajukan pembiayaan dengan skema mudharabah. Dalam waktu singkat pertumbuhan perbankan syariah akan mengungguli perbankan konvensional. Namun kembali lagi, fakta yang terjadi di lapangan tidak seperti teori. Perbankan syariah yang ada belum sungguh-sungguh menerapkan fatwa DSN secara utuh. Sehingga pelaku usaha yang mendapatkan pembiayaan modal dari perbankan syariah, masih diwajibkan mengembalikan modal secara utuh, walaupun ia mengalami kerugian usaha. Terlalu banyak cerita dari nasabah mudharabah bank syariah yang mengalami perlakuan ini. Selain itu status Bank Syariah juga perlu mendapatkan perhatian. Dalam fatwa diatas jelas dinyatakan bahwa status modal adalah mutlak milik pemilik modal/shohibul mal dan status agen adalah orang yang mengelola modal/uang milik pemodal untuk usaha perdagangan. Namun hal ini tidak berlaku pada sistem perbankan syariah. Bank syari'ah memiliki status ganda, yaitu sebagai pemodal dan juga sebagai agen dalam satu waktu. Bank berperan sebagai pelaku usaha, yaitu ketika pada pagi hari, bank berhubungan dengan nasabah (kreditur) pemilik modal. Namun dalam sekejap status ini berubah, dimana pada siang harinya bank berperan sebagai pemodal, yaitu jika bank berhadapan dengan pelaku usaha yang membutuhkan modal usaha. Status ganda yang diperankan oleh bank ini membuktikan bahwa akad yang sebenarnya dijalankan selama ini adalah akad hutang piutang dan bukan akad mudharabah.(Afandi, 2012)
M. Arifin bin Badri, MA., dalam bukunya Riba \& Tinjauan Kritis Perbankan Syariah, mengutip perkataan Imam An-Nawawi sebagai berikut: (Afandi, 2012)

"Tidak dibenarkan bagi pelaku usaha (mudharib) untuk menyalurkan modal yang ia terima kepada pihak ketiga dengan akad mudharabah. Jika ia melakukan hal itu atas seizin pemodal, sehingga ia keluar dari akad mudharabah pertama dan berubah statusnya menjadi perwakilan/mediator bagi pemodal pada akad mudharabah kedua ini, maka itu dibenarkan. Akan tetapi ia tidak dibenarkan untuk mensyaratkan bagi dirinya sedikitpun dari keuntungan yg diperoleh. Bila ia tetap mensyaratkan hal itu, maka akad mudharabah kedua tidak syah/batal".

Kondisi dalam kontrak mudharabah menyebutkan bahwa kerugian usaha ditanggung $100 \%$ oleh pemilik modal jika mudharib tidak melakukan kelalaian yang mengakibatkan terjadinya kerugian dan juga kondisi kontrak yang tidak membenarkan penyertaan jaminan asset/modal mudharib baik sebagian maupun keseluruhannya. Para ulama dari berbagai madzhab telah menegaskan bahwa pemilik modal tidak dibenarkan untuk mensyaratkan agar pelaku usaha memberikan jaminan seluruh atau sebagian modalnya. Sehingga apa yang diterapkan pada perbankan syari'ah, yaitu mewajibkan atas pelaku usaha untuk mengembalikan seluruh modal dengan utuh jika terjadi kerugian usaha adalah persyaratan yang tidak benar. Namun kondisi-kondisi tersebut tidak berlaku dalam praktek 
mudharabah bank syari'ah. Bank tidak mau menanggung kerugian jika usaha mengalami kegagalan/kerugian. Jika terjadi kerugian usaha, niscaya bank akan meminta kembali modal yang telah ia kucurkan dengan utuh.

Dalam praktek perbankan syariah dewasa ini, perbankan seringkali memberikan hadiah pada saat kita menjadi nasabah di bank syariah. Hadiah yang diberikan dapat diperoleh nasabah pada awal menjadi nasabah ataupun setelah menjadi nasabah. Jika hadiah diberikan setelah nasabah, biasanya dana pemberian hadiah dialokasikan dari sisa pendapatan operasional bank. Akan tetapi, sekarang ini hadiah tidak hanya diberikan setelah menjadi nasabah, melainkan ditawarkan kepada pihak yang baru akan menjadi nasabah. Hadiah yang ditawarkan dapat berupa uang tunai, emas, kendaraan atau perjalanan umrah. Hadiah ini diberikan pada nasabah yang mendepositokan uangnya dalam jumlah yang cukup besar (minimal 50 juta rupiah). Hal ini oleh sebagian ulama dianggap tidak sesuai dengan syariat Islam, karena pemberian hadiah dilakukan dimuka, sebelum dana yang disimpan di bank digunakan untuk usaha dan menghasilkan tingkat keuntungan yang bisa dibagi antara pemilik dana dengan pengelola.

Penelitian ini merupakan penelitian eksplorasi, dengan pengumpulan data sekunder dari perbakan syariah dan membandingkan dengan teori yang diperoleh melalui studi kepustakaan. Permasalahan yang ada dilihat dari berbagai literatur, kemudian dianalisis untuk diambil kesimpulan.

\section{HASIL DAN PEMBAHASAN Pengertian Mudharabah}

Mudaharabah disebut juga Muqarradah yang berarti bepergian untuk urusan dagang. Secara bahasa, mudharabah berasal dari kata $a d h$ dharb yang memiliki dua relevansi antara keduanya, yaitu; pertama, karena yang melakukan usaha ('amil) yadhribu filardhi (berjalan dimuka bumi) dengan bepergian untuk berdagang, maka ia berhak mendapatkan keuntungan karena usaha dan kerja kerasnya. Kedua, karena masingmasing orang yang berserikat yadhribu

bisahmin (memotong/mengambil

bagian) dalam keuntungan (Ibnu Faris, 1972). Kata mudharabah ini mempunyai beberapa sinonim, yaitu muqaradha, qirad atau muamalah. Perbedaan ini terletak dalam hal kebiasaan penyebutan dari tiap-tiap daerah Islam. Masyarakat Irak menggunakannya dengan istilah mudharabah atau kadangkala juga muamalah, masyarakat Islam Madinah atau wilayah Hijaz lainnya menyebutnya

dengan muqaradha atau qirad (Ala', 2000).

Mudharabah memiliki 2 type, yaitu: 1) Mudharabah Mutlaqah: Dimana shahibul maal memberikan keleluasaan penuh kepada pengelola (mudharib) untuk mempergunakan dana tersebut dalam usaha yang dianggapnya baik dan menguntungkan. Namun pengelola tetap bertanggung jawab untuk melakukan pengelolaan sesuai dengan praktek kebiasaan usaha normal yang sehat (uruf), dan 2)Mudharabah Muqayyadah: Dimana pemilik dana menentukan 
syarat dan pembatasan kepada pengelola dalam penggunaan dana tersebut dengan jangka waktu, tempat, jenis usaha dan sebagainya (Abdul, 1997 : 393).

\section{Pendanaan Dengan Prinsip Mudharabah}

1. Tabungan Mudharabah Bank dapat mengintegrasikan rekening tabungan dengan rekening investasi dengan prinsip mudharabah dengan bagi hasil yang disepakati bersama. Mudharabah merupakan prinsip bagi hasil dan bagi kerugian ketika nasabah sebagai pemilik modal (shahibul mal) menyerahkan uangnya kepada bank sebagai pengusaha (mudharib) untuk diusahakan. Keuntungan dibagi sesuai kesepakatan dan kerugian ditanggung oleh pemilik dana atau nasabah.

2. Deposito/Investasi Umum (Tidak Terikat)

bank syariah menerima simpanan deposito berjangka (pada umunya untuk satu bulan ke atas) ke dalam rekening investasi umum (general investment account) dengan prinsip mudharabah al muthlaqah. Investasi umum ini sering disebut juga sebagai investasi tidak terikat. Nasabah rekening investasi lebih bertujuan untuk mencari keuntungan daripada untuk mengamankan uangnya. Dalam mudharabah al muthlaqah, bank sebagai mudharib mempunyai kebebasan mutlak dalam pengelolaan investasinya.
3. Deposito/Investasi Khusus (Terikat)

Bank syariah juga menawarkan rekening khusus (special investment account) kepada nasabah yang ingin menginvestasikan dananya langsung dalam proyek yang disukainya yang dilaksanakan oleh bank dengan prinsip mudharabah al muqayyadah. Investasi khusus ini sering disebut juga sebagai investasi terikat. Rekening investasi khusus ini biasanya ditujukan kepada para nasabah/investor besar dan institusi. Dalam mudharabah al muqayyadah bank menginvestasikan dana nasabah ke dalam proyek tertentu yang diinginkan nasabah. Jangka waktu investasi dan bagi hasil disepakati bersama dan hasilnya langsung berkaitan dengan keberhasilan proyek investasi yang dipilih.

4. Sukuk Al-Mudharabah

Akad mudharabah juga dapat dimanfaatkan oleh bank syariah untuk penghimpunan dana dengan menerbitkan Sukuk yang merupakan obligasi syariah. Dengan obligasi syariah, bank mendapatkan alternatif sumber dana berjangka panjang (lima tahun atau lebih) sehingga dapat digunakan untuk pembiayaanpembiayaan berjangka panjang (Ascarya, 2007 : 117).

\section{Fatwa Tentang Pembiayaan Mudharabah (Qiradh)}

Ketentuan Pembiayaan(DSN-MUI, 2000):

1. Pembiayaan Mudharabah adalah pembiayaan yang disalurkan 
oleh Lembaga Keuangan Syariah (LKS) kepada pihak lain untuk suatu usaha yang produktif.

2. Dalam pembiayaan ini LKS sebagai shahibul maal (pemilik dana) membiayai $100 \%$ kebutuhan suatu proyek (usaha), sedangkan pengusaha (nasabah) bertindak sebagai mudharib atau pengelola usaha.

3. Jangka waktu usaha, tatacara pengembalian dana, dan pembagian keuntungan ditentukan berdasarkan kesepakatan kedua belah pihak (LKS dengan pengusaha).

4. Mudharib boleh melakukan berbagai macam usaha yang telah disepakati bersama dan sesuai dengan syari'ah; dan LKS tidak ikut serta dalam managemen perusahaan atau proyek tetapi mempunyai hak untuk melakukan pembinaan dan pengawasan.

5. Jumlah dana pembiayaan harus dinyatakan dengan jelas dalam bentuk tunai dan bukan piutang.

6. LKS sebagai penyedia dana menanggung semua kerugian akibat dari mudharabah kecuali jika mudharib (nasabah) melakukan kesalahan yang disengaja, lalai, atau menyalahi perjanjian.

7. Pada prinsipnya, dalam pembiayaan mudharabah tidak ada jaminan, namun agar mudharib tidak melakukan penyimpangan, LKS dapat meminta jaminan dari mudharib atau pihak ketiga. Jaminan ini hanya dapat dicairkan apabila mudharib terbukti melakukan pelanggaran terhadap hal-hal yang telah disepakati bersama dalam akad.

8. Kriteria pengusaha, prosedur pembiayaan, dan mekanisme pembagian keuntungan diatur oleh LKS dengan memperhatikan fatwa DSN.

9. Biaya operasional dibebankan kepada mudharib.

10. Dalam hal penyandang dana (LKS) tidak melakukan kewajiban atau melakukan pelanggaran terhadap kesepakatan, mudharib berhak mendapat ganti rugi atau biaya yang telah dikeluarkan.

Rukun dan Syarat Pembiayaan:

1. Penyedia dana (sahibul maal) dan pengelola (mudharib) harus cakap hukum.

2. Pernyataan ijab dan qabul harus dinyatakan oleh para pihak untuk menunjukkan kehendak mereka dalam mengadakan kontrak (akad), dengan memperhatikan hal-hal berikut:

a. Penawaran dan penerimaan harus secara eksplisit menunjukkan tujuan kontrak (akad).

b. Penerimaan dari penawaran dilakukan pada saat kontrak.

c. Akad dituangkan secara tertulis, melalui korespondensi, atau dengan menggunakan cara-cara komunikasi modern.

3. Modal ialah sejumlah uang dan/atau aset yang diberikan oleh penyedia dana kepada mudharib untuk tujuan usaha dengan syarat sebagai berikut:
a. Modal harus diketahui jumlah dan jenisnya.
b. Modal dapat berbentuk uang atau barang yang dinilai. Jika 
modal diberikan dalam bentuk aset, maka aset tersebut harus dinilai pada waktu akad.

c. Modal tidak dapat berbentuk piutang dan harus dibayarkan kepada mudharib, baik secara bertahap maupun tidak, sesuai dengan kesepakatan dalam akad.

4. Keuntungan mudharabah adalah jumlah yang didapat sebagai kelebihan dari modal. Syarat keuntungan berikut ini harus dipenuhi:

a. Harus diperuntukkan bagi kedua pihak dan tidak boleh disyaratkan hanya untuk satu pihak.

b. Bagian keuntungan proporsional bagi setiap pihak harus diketahui dan dinyatakan pada waktu kontrak disepakati dan harus dalam bentuk prosentasi (nisbah) dari keuntungan sesuai kesepakatan. Perubahan nisbah harus berdasarkan kesepakatan.

c. Penyedia dana menanggung semua kerugian akibat dari mudharabah, dan pengelola tidak boleh menanggung kerugian apapun kecuali diakibatkan dari kesalahan disengaja, kelalaian, atau pelanggaran kesepakatan.

5. Kegiatan usaha oleh pengelola (mudharib), sebagai perimbangan (muqabil) modal yang disediakan oleh penyedia dana, harus memperhatikan hal-hal berikut: a) Kegiatan usaha adalah hak eksklusif mudharib, tanpa campur tangan penyedia dana, tetapi ia mempunyai hak untuk melakukan pengawasan. b) Penyedia dana tidak boleh mempersempit tindakan pengelola sedemikian rupa yang dapat menghalangi tercapainya tujuan mudharabah, yaitu keuntungan. c.) Pengelola tidak boleh menyalahi hukum Syari'ah Islam dalam tindakannya yang berhubungan dengan mudhara-bah, dan harus mematuhi kebiasaan yang berlaku dalam aktifitas itu.

\section{Pengertian Hadiah (Al-Athiyah)}

Menurut istilah syar'i, hadiah ialah menyerahkan suatu benda kepada seorang tertentu agar terwujudnya hubungan baik dan mendapatkan pahala dari Allah tanpa adanya permintaan dan syarat(Ihsan,). Dalam pengertian tersebut ada sisi keumuman dan kekhususan di kalangan para ulama antara hibah, pemberian (athiyah) dan shadaqah. Perbedaan definisi di antara tiga perkara ini adalah niat, maka shadaqah diberikan kepada seseorang yang membutuhkan dan dalam rangka mencari ridha Allah. Terkadang pemberian hadiah itu juga bertujuan untuk mencari ridha Allah. Adapun hibah dan athiyah, tidak ada di antara keduanya perbedaan dan terkadang dimaksudkan untuk memuliakan orang yang diberikan hibah atau athiyah saja dikarenakan suatu keistimewaan atau sebab tertentu dari sebab-sebab yang ada.

\section{Hukum Hadiah}


Diperbolehkan dengan kesepakatan ulama, dan apabila tidak terdapat di sana larangan yang syar'i. Terkadang disunnahkan untuk memberikan hadiah apabila dalam rangka menyambung silaturrahim, kasih sayang dan rasa cinta. Terkadang disyariatkan apabila dia termasuk di dalam urusan 'Membalas Budi dan Kebaikan Orang Lain dengan Hal yang Semisalnya'. Terkadang bisa menjadi haram apabila merupakan hadiah yang berbentuk suatu yang haram, atau termasuk dalam kategori sogok-menyogok dan yang sehukum dengannya.

\section{Hukum Menerima Hadiah}

Para ulama berselisih pendapat tentang orang yang diberikan bingkisan hadiah, apakah wajib menerimanya atau disunnahkan saja? Dan pendapat yang kuat bahwasanya orang yang diberikan hadiah yang mubah dan tidak ada penghalang syar'i yang mengharuskan menolaknya, maka wajib menerimanya, dikarenakan dalil-dalil berikut ini:1) Rasulullah shallallahu 'alaihi wasallam bersabda, "Penuhilah undangan, jangan menolak hadiah, dan janganlah menganiaya kaum muslimin.” (Shahihul Jami':158) 2) Di dalam Ash Shahihain (Al Bukhari dan Muslim) dari Umar radhiyallahu 'anhu, beliau berkata, "Rasulullah shallallahu 'alaihi wasallam memberiku sebuah bingkisan, lalu aku katakan, 'Berikan ia kepada orang yang lebih fakir dariku', maka beliau menjawab, 'Ambillah, apabila datang kepadamu sesuatu dari harta ini, sedangkan engkau tidak tamak dan tidak pula memintanya, maka ambillah dan simpan untuk dirimu, jikalau engkau menghendakinya, maka makanlah. Dan bila engkau tidak menginginkannya, bershadaqahlah dengannya." Salim bin Abdillah berkata, "Oleh karena itu, Abdullah bin Umar tidak pernah meminta kepada orang lain sedikitpun, dan tidak pula menolak bingkisan yang diberikan kepadanya sedikitpun." (Shahih At Targhib) Dan di dalam sebuah riwayat, Umar radhiyallahu 'anhu berkata, "Ketahuilah demi Dzat yang jiwaku di tangan-Nya! Saya tidak akan meminta kepada orang lain sedikitpun, dan tidaklah aku diberikan suatu pemberian yang tidak aku minta melainkan aku mengambilnya...."((Shahih At Targhib). 3) Rasulullah shallallahu 'alaihi wasallam tidaklah menolak hadiah kecuali dikarenakan sebab yang syar'i sebagaimana akan dijelaskan sebentar lagi. Oleh karena adanya dalil-dalil ini, maka wajib menerima hadiah apabila tidak dijumpai larangan syar'i. 4) Demikian pula di antara dalil-dalil yang menunjukkan wajibnya, adalah apa yang diriwayatkan oleh Imam Ahmad dari hadits Abu Hurairah radhiyallahu'anhu. Beliau berkata bahwa Rasulullah shallallahu 'alaihi wasallam pernah bersabda, "Barangsiapa yang Allah datangkan kepadanya sesuatu dari harta ini, tanpa dia memintanya, maka hendaklah dia menerimanya, karena sesungguhnya itu adalah rezeki yang Allah kirimkan kepadanya." (Shahih At Targhib) dan di dalam riwayat lain dari Khalid Al Jahnany radhiyallahu 'anhu, beliau berkata, "Saya pernah mendengar Rasulullah shallallahu 'alaihi wasallam bersabda, "Barangsiapa yang sampai kepadanya sebuah kebaikan dari 
saudaranya dengan tanpa meminta dan tamak, hendaklah dia menerimanya dan tidak menolaknya, karena sesungguhnya itu merupakan rezeki yang Allah Azza wa Jalla kirimkan kepadanya" (Shahih At Targhib wat Tarhib). Maka menjadi kuatlah pendapat yang mengatakan wajibnya menerima hadiah apabila tidak ada di sana larangan syar'i.

\section{Hukum Menolak Hadiah}

Hadiah tidak boleh ditolak kecuali dikarenakan udzur syar'i, dan Nabi SAW melarang kita untuk menolak hadiah dengan sabda beliau, "Jangan kalian menolak hadiah." Terkadang, Nabi SAW menolak hadiah dikarenakan satu sebab dari sebabsebab yang ada, di antaranya: 1) Di dalam Ash Shahihain dari hadits Ash Sha'bu bin Jutsamah radhiyallahu 'anhu, bahwasanya beliau memberi hadiah kepada Rasulullah shallallahu 'alaihi wasallam berupa seekor keledai liar, lalu beliau shallallahu 'alaihi wasallam menolaknya. Maka tatkala beliau melihat ada sesuatu di raut wajah Ash Sha'bu, beliau berkata, "Ketahuilah, sesungguhnya kami tidak menolaknya, hanya saja kami dalam keadaan sedang berihram"( Shahih At Targhib wat Tarhib) Ibnu Hajar berkata, "Di dalam hadits ini ada dalil bahwasanya tidak boleh menerima hadiah dan tidak halalnya hadiah ketika ihram". 2) Dalam Ash Shahihain dari hadits Ibnu Abbas radhiyallahu 'anhuma, beliau berkata, "Ummu Hafid, bibinya Ibnu Abbas pernah memberikan hadiah kepada Nabi SAW berupa tepung aqith, minyak samin dan daging dhab (sejenis biawak). Lalu Rasulullah shallallahu 'alaihi wasallam makan tepung aqith dan minyak samin, namun meninggalkan daging dhab dikarenakan merasa jijik."(H.R Bukhari dan Muslim : 1544) dan dalam hadits ini ada beberapa faidah: a) Bolehnya menerima hadiah dari para wanita apabila aman dari fitnah. b) Bolehnya menolak hadiah dikarenakan suatu sebab. c) Seseorang yang memberi hadiah tidak boleh merasa sedih apabila hadiahnya ditolak, dan hendaknya dia memberi udzur bagi orang yang menolaknya, atau tidak boleh merasa berduka, selama alasannya jelas. 4) Dan di dalam Abu Dawud, dari Abu Hurairah radhiyallahu 'anhu bahwasanya Nabi shallallahu 'alaihi wasallam bersabda, "Demi Allah, saya tidak akan menerima hadiah dari seorang pun setelah hari ini kecuali dia seorang Muhajir Quraisy, atau seorang Anshar, atau seorang dari suku Daus atau seorang dari suku Tsaqif."( HR. Abu Dawud, At Tirmidzi, Shahih Adabul Mufrad [464], Ash Shahihah [1684). Pernah ada seorang arab gunung memberikan kepada Nabi shallallahu 'alaihi wasallam seekor unta lalu beliau menggantinya, maka sang badui ini memarahi beliau, lalu beliau shallallahu 'alaihi wasallam menambahnya dan bersabda, "Apakah kamu telah ridha?" Dia menjawab, "Tidak." Lalu ditambah lagi oleh beliau hingga beliau menggantinya dengan enam ekor unta." Dan di dalam hadits ini ada dalil yang menunjukkan bolehnya menolak hadiah apabila dia khawatir muncul fitnah dari hadiah tersebut, atau terdapat penghinaan terhadap orang yang mengambil hadiah tersebut. Nabi Sulaiman 'alahissalam menolak hadiah Ratu Balqis 
dikarenakan ia merupakan suapmenyuap di dalam perkara agama agar Sulaiman 'alaihissalam diam darinya dan membiarkan dia beribadah kepada matahari. Apabila hadiah tersebut berupa suapmenyuap untuk membatalkan kebenaran dan melegalkan kebatilan, maka tidak boleh diterima ketika itu. Dan demikian pula apabila hadiah tersebut diperuntukkan bagi para pemimpin, para menteri, dan para pejabat, agar mereka memberimu sesuatu yang bukan menjadi hakmu, atau mereka memaafkan kamu dari sesuatu yang tidak pantas untuk mereka maafkan, maka ketika itu haram bagimu memberikan hadiah dan haram bagi mereka menerima hadiah tersebut dikarenakan itu merupakan suap-menyuap, dan sungguh Rasulullah shallallahu 'alaihi wasallam bersabda, "Allah melaknat orang yang menyuap dan orang yang menerima suap di dalam hukum."(Shahihul Jama'i : 5093) Dan demikian pula apabila hadiah tersebut berupa barang curian atau barang haram. Maka tidak boleh diterima karena yang demikian itu termasuk makan barang haram dan termasuk tolong-menolong di atas dosa dan permusuhan. Begitu juga apabila yang memberi hadiah tersebut menganggap hadiahnya sebagai hutang bagimu dan kamu tidak menginginkan untuk menanggung hutang tersebut, baik secara syar'i maupun secara kebiasaan, maka boleh bagimu untuk menahan diri dari mengambilnya disertai dengan meminta udzur. Dan demikian pula bila sang pemberi hadiah tersebut adalah seorang yang suka mengungkit-ungkit pemberiannya dan menceritakannya, maka tidak boleh diterima hadiah itu darinya.

Kesimpulannya, hukum asal adalah wajib menerima hadiah dan tidak boleh menolaknya kecuali apabila didapati larangan syar'i atau udzur maka boleh menolaknya.

\section{Uqud Al-Tamlikat}

$\begin{array}{rcc}\text { 'Uqud } & \text { al-Tamlikat } & \text { adalah } \\ \text { akad yang } & \text { tujuannya } & \text { adalah } \\ \text { memindahkan } & \text { suatu } & \text { hak }\end{array}$ kepemilikan benda dari satu pihak kepada pihak yang lainnya. Jenis akad ini terbagi 2 lagi yaitu: yang pertama: 'uqud-al mu'awadat yaitu akad pertukaran benda antara kedua belah pihak, di mana masing-masing pihak memiliki sesuatu yang akan di tukar hak kepemilikannya kepada pihak yang lainnya, seperti transaksi jual-beli, dan transaksi valuta asing; yang kedua: uqud al-tabarru'at yaitu akad yang dilakukan berdasarkan keinginan sukarela dari satu pihak yang berkeinginan untuk memindahkan hak kepemilikan bendanya kepada pihak lain tanpa mengharapkan mendapatkan sesuatu dari pihak lainnya, contohnya adalah hibah, waqf, sedekah.

\section{Kejelasan Status Kepemilikan Modal dan Status Mudharib}

Secara teknis, mudharabah adalah akad kerja sama usaha antara dua pihak,di mana pihak pertama menyediakan seluruh (100 persen) modal, sedangkan pihak lain menjadi pengelola. Keuntungan usaha secara mudharabah dibagi menurut kesepakatan yang dituangkan dalam kontrak, sedangkan apabila rugi, ditanggung oleh pemilik modal selama kerugian tersebut bukan akibat kelalaian di pengelola. 
Seandainya kerugian itu diakibatkan karena kecurangan atau kelalian si pengelola, maka pengelola harus bertanggung jawab atas kerugian tersebut. (Abdurrahman, $1992: 15$ )

Dalam poin ini jelas dinyatakan bahwa status modal adalah mutlak milik pemilik modal/shohibul mal dan status agen adalah orang yang mengelola modal/uang milik pemodal untuk usaha perdagangan . Namun hal ini tidak berlaku pada sistem perbankan syariah. Bank syari'ah memiliki status ganda, yaitu sebagai pemodal dan juga sebagai agen dalam satu waktu. Bank menerima dana dari nasabah (berlaku sebagai pengelola), kemudian bank menyalurkan dana tersebut sebagai pembiayaan kepada nasabah lain (dalam hal ini bak bertindak sebagai pemilik dana). Status ganda yang diperankan oleh bank ini membuktikan bahwa akad yang sebenarnya dijalankan selama ini adalah akad hutang piutang dan bukan akad mudharabah. Kadangkala bank berkilah bahwa dana titipan nasabah berbentuk wadhiah yad dhamanah (barang titipan yang bisa dipergunakan), dimana bank memiliki hak untuk menggunakannya, hal itu dlakukan hanya sebagai pembenaran saja, (pemelintiran istilah dayn/qard menjadi wadi'ah) agar bank memiliki legalitas mengelola titipan uang nasabah dan selanjutnya dapat menjalankan skenario mudharabah sebagai pemilik modal. Perlu diketahui, bahwa hukum asal barang titipan adalah mubah dengan ketentuan si penerima titipan wajib menjaga amanah barang yang dititipinya dan tidak boleh menggunakan barang titipan tersebut baik seizin maupun tanpa izin pemilik barang, dan apabila ketentuan ini dilanggar, maka si penerima titipan telah berkhianat karena tidak dapat menjalankan amanah.

Dana nasabah yang berupa titipan/wadi'ah itu digunakan oleh bank untuk disalurkan kepada pihak ketiga, yaitu para pengusaha yang memerlukan modal usaha melalui skema mudharabah/bagi hasil, dimana bank bertindak sebagai pemilik modal/shohibul maal sedangkan pengusaha sebagai agen/mudharib. Kerancuan hukum mulai tampak pada skema mudharabah ini. Dana nasabah (wadi'ah) yang seharusnya dijaga dan tidak boleh dipergunakan, namun bank mempergunakannya untuk kepentingan bisnis demi mencari keuntungan dengan menyalurkan kembali kepada pihak ketiga. Dengan demikian, dalam pandangan Hukum Islam akad mudharabah versi bank syari'ah ini tidak dibenarkan dan berubah akadnya menjadi akad qard/dayn (peminjaman/piutang) karena bank memiliki hak kepemilikan utuh atas dana nasabah yang dititipkannya dan selanjutnya dana tersebut dimanfaatkan untuk kepentingan kontrak bisnis yang mendatangkan keuntungan. Dalam kaidah fiqih disebutkan bahwa setiap piutang yang mendatangkan kemanfaatan/ keuntungan, maka itu adalah riba.

Status berikutnya, yaitu bank bertindak sebagai mudharib (agen) juga tidak bisa diterima. Alasannya adalah ketika pemilik modal (nasabah) membuat kontrak mudharabah kepada pihak bank dengan cara menunjuk pihak bank 
sebagai pihak kedua (mudharib) yang akan mengelola dana nasabah dalam pembiayaan suatu usaha, ternyata bank melanggar kontrak tersebut. Hal ini terjadi karena bank tidak memilik usaha sektor riil yang akan mendatangkan keuntungan usaha, melainkan hanya produk perbankan yang semuanya sebatas pembiayaan dan pendanaan. Peran perbankan hanya penyalur dana nasabah dan tidak berperan sebagai pelaku usaha (mudharib) karena takut menanggung resiko usaha serta ingin mendapatkan keuntungan saja. Dikarenakan bank tidak memiliki usaha riil, maka lagi-lagi bank menyalurkan dana nasabah kepada pihak ketiga yang memerlukan modal usaha sebagaimana skema mudaharabah dengan menggunakan dana titipan nasabah (wadi'ah).

\section{Bank Tidak Mau Menanggung Resiko Kerugian}

Kondisi dalam kontrak mudharabah menyebutkan bahwa kerugian usaha ditanggung 100\% oleh pemilik modal jika agen tidak melakukan kelalaian yang mengakibatkan terjadinya kerugian. Kondisi tersebut tidak berlaku dalam praktek mudharabah bank syari'ah. Bank tidak mau menanggung kerugian jika usaha mengalami kegagalan/kerugian. Jika terjadi kerugian usaha, niscaya bank akan meminta kembali modal yang telah dikucurkan dengan utuh. Untuk menghilangkan resiko kerugian sedini mungkin, sebelum kontrak perjanjian disepakati, bank meminta jaminan asset/modal dari nasabah pelaku usaha yang selanjutnya akan dijadikan sebagai instrument pembayaran modal pinjaman jika terjadi kerugian atau kegagalan usaha.

Para ulama dari berbagai madzhab telah menegaskan bahwa pemilik modal tidak dibenarkan untuk mensyaratkan agar pelaku usaha memberikan jaminan seluruh atau sebagian modalnya. Sehingga apa yang diterapkan pada perbankan syari'ah, yaitu mewajibkan atas pelaku usaha untuk mengembalikan seluruh modal dengan utuh jika terjadi kerugian usaha adalah persyaratan yang tidak benar.

\section{Bank Memberikan Hadiah Di Muka pada Saat Menyetorkan Dana Deposito}

Hadiah atau hibah dalam transaksi ekonomi syariah masuk dalam golongan akad uqud al-Tamlikat yaitu akad-akad perpindahan hak kepemelikan dari satu pihak kepada pihak yang lain nya. Untuk uqud altamlikat di bagi ke dalam dua katagori yaitu: 1) Uqud al-muawadat (contract of exchange) yaitu akad pertukaran hak kepemilikan di antara dua belah pihak, contoh nya akad jual-beli atau bai', dan 2) Uqud tabarruat (unilateral contract) yang arti-nya adalah akad sukarela dimana transaksi perpindahan barang atau uang terjadi satu arah, di mana satu pihak memindahkan hak kepemilikan barang nya kepada pihak lain, sebagai penerima dari hadiah dalam bentuk hibah, sedekah, zakat, wakaf, wasiat/warisan.

Kalau bank memberi hadiah kepada setiap nasabahnya tanpa harus mensyaratkan nasabah nya untuk membuka rekening baru di bank syariah tersebut maka transaksi nya menjadi halal, karena itu adalah hibah murni atau hadiah sesuai dengan akad tabarruat. Tetapi 
karena bank syariah memberi hadiah kepada nasabah dengan syarat nasabah membuka rekening baru dan menyetorkan sejumlah uang untuk di titipkan (wadiah) pada bank, maka terjadi ketidak adilan di sini.

Praktek pemberian hadiah yang dilakukan perbankan syariah dapat digambarkan secara detil pada table 1 dibawah ini. Pada table 1 dapat dilihat bahwa hadiah berupa uang tunai diberikan di awal sebesar 0,5 persen dari dana yang disetorkan. Hadiah ini dapat dipilih, berupa uang tunai, emas setara dengan uang tunai atau perjalanan umrah. Jika nasabah setuju untuk menimpan dananya, maka nasabah akan mendapatkan bagi hasil lagi sesuai dengan kesepakatan yang dibuat dengan pihak perbankan. Hal yang dilakukan perbankan syariah ini bertentangan dengan syariat Islam karena pemberian hadiah ini diiringi dengan maksud-maksud tertentu, yaitu agar nasabah menempatkan dananya pada perbankan syariah. Hal ini dilakukan sebagai salah satu bentuk promosi dalam menarik nasabah agar mau menempatkan dananya pada perbankan syariah.

\section{PENUTUP}

Beberapa kesimpulan yang dapat diambil dari penulisan ini adalah:

1. Praktek mudharabah di perbankan syariah belum benar-benar diterapkan sesuai dengan fatwa Dewan Syariah Nasional Majelis Ulama Indonesia.

2. Perbankan syariah tidak bersedia menanggung kerugian sebagaimana yang dinyatakan dalam fatwa No 07/DSN-MUI/IV/2000
Tentang
Mudharabah. Pembiayaan

3. Perbankan syariah berperan ganda, sebagai mudharib dan juga sekaligus sebagai pemilik dana.

4. Pemberian hadiah dimuka yang dilakukan oleh perbankan syariah pada saat nasabah menyetorkan dana tidak dapat dibenarkan menurut syariat karena diiringi dengan maksudmaksud tertentu.

\section{REFERENSI}

Abdurrahman Hamdi, 1992 Islamic Banking Conceptual Frame Work and Practical Operation, (Fakistan: Institue of Policy Studies Islam Abad), $1^{\text {st }}$ edition

Alquran surat Al Hasyr 59:7

Ala' Edin Kharofa, 2000 Transaction in Islamic Law, (Kuala Lumpur: A.S Noordeen), cet ke-1

Ascarya, 2007; Akad dan Produk Bank Syariah, PT. Rajagrafindo Persada, Jakarta

Ashgar Ali Engineer. 2006, Islam dan Teologi Pembebasan. Pustaka Pelajar Yogyakarta

Afandi, Rahmat (2012); Penyimpangan Praktek Mudharabah Bank Syariah, (online)

http://www.wakalanusantara. com, diakses tanggal 17 Oktober 2012

Badri, M. Arifin, MA (2009)., Riba \& Tinjauan Kritis Perbankan Syariah, Pustaka Darul Ilmi,

Dewan Syariah Nasional-Majelis Ulama Indonesia, (2000); Fatwa 07/DSN-MUI/IV/2000 
Tentang Pembiayaan

Mudharabah, Jakarta

Ibnu Faris, Mu'jam Maqayis alLughah 1972 (Kairo;Majma' al-lughoh al 'arabiyah,), vol. 5

Ihsan, Fadhil; Hukum Hadiah dalam Islam, online (http://fadhlihsan.wordpress.c om) Jurnal Salafiyun diakses tanggal 23 Oktober 2012
Karim, Adiwarman A (2006); Bank Islam, Analisis Fiqih dan Keuangan, Edisi 3, PT Raja Grafindo Persada, Jakarta,

M. Abdul Mannan, 1997 Teori dan Praktek Ekonomi Islam, (Yogyakarta: Dana bakti Wakaf), 